\title{
Protective efficacy of commercial vaccines against a virulent field strain of Clostridium chauvoei
}

\section{Eficácia protetiva de vacinas comerciais contra uma cepa de campo virulenta de Clostridium chauvoei}

\author{
Rosangela Estel Ziech ${ }^{1 *}$; Luana D’Ávila Farias²; Cláudia Balzan³; \\ Monique Aldren Burnett da Luz ${ }^{4}$. Joachim Frey ${ }^{5}$; Agueda Castagna de Vargas ${ }^{6}$
}

\begin{abstract}
Blackleg is an acute and frequently fatal infection that mainly affects cattle and is caused by Clostridium chauvoei. Formalin-killed, whole-cell vaccines are commonly used to control blackleg. The aim of this study was to verify the protective efficacy of two commercial vaccines against the infection of guinea pigs with two strains of C. chauvoei, a virulent field strain (SBP 07/09) and the reference strain used in official tests (Manguinhos-Teixeira or MT). The strains used in the challenge were characterized by whole genome sequencing, and the minimal inhibitory concentrations of 15 antimicrobials were determined. To assess the protective efficacy, guinea pigs were vaccinated and subsequently challenged with $C$. chauvoei. All four vaccinated and challenged groups seroconverted after vaccination, while the control group remained seronegative, as determined by indirect ELISA. The identical performance of the two C. chauvoei strains in terms of virulence after challenge and their inability to infect vaccinated animals was correlated with their high genetic homology. Both commercial vaccines showed good protective efficacy against both the reference and field strains. Although $C$. chauvoei vaccination failures have been reported, the results from our study and others reported high similarity among $C$. chauvoei strains from all over the world, which suggests that the vaccine failures are not due to antigenic variability but inadequate vaccine management.
\end{abstract}

Key words: Blackleg. Clostridial diseases. Mionecrosis. Bacterins. Evaluation.

\section{Resumo}

O carbúnculo sintomático é uma infecção aguda e frequentemente fatal que afeta principalmente os bovinos, causada pelo Clostridium chauvoei. A administração de vacinas formolizadas compostas pelas células bacterianas inteiras é comumente utilizada no controle desta doença. O objetivo deste estudo foi verificar, em cobaios, a eficácia protetiva de duas vacinas comerciais contra duas cepas de Clostridium chauvoei, uma cepa de campo virulenta (SBP 07/09) e a cepa de referência utilizada nos testes oficiais (MT, Manguinhos-Teixeira). Adicionalmente, realizar a caracterização das cepas utilizadas no desafio pelo sequenciamento completo do genoma e pela determinação da concentração inibitória mínima frente a 15 antimicrobianos. Para tanto, os cobaios foram vacinados e subsequentemente desafiados $\operatorname{com} C$.

1 Discente, Departamento de Medicina Veterinária Preventiva, Universidade Federal de Santa Maria, UFSM, Santa Maria, RS, Brasil. E-mail: reziech@gmail.com

2 Pesquisadora, Secretaria da Agricultura, Pecuária e Irrigação, Caiçara, RS, Brasil. E-mail: luana.vett@gmail.com

3 Discente, Departamento de Medicina Veterinária Preventiva, UFSM, Santa Maria, RS, Brasil. E-mail: cl.balzan@gmail.com

4 Discente, Curso de Graduação em Medicina Veterinária, UFSM, Santa Maria, RS, Brasil. E-mail: niqmedvet@outlook.com

5 Prof., Instituto de Bacteriologia Veterinária, Universidade de Berna, Berna, Suíça. E-mail: joachim.frey@vetsuisse.unibe.ch

6 Prof ${ }^{a}$, Departamento de Medicina Veterinária Preventiva, UFSM, Santa Maria, RS, Brasil. E-mail: agueda.vargas@gmail.com Authot for correspondence 
chauvoei. Os quatro grupos vacinados e desafiados soroconverteram, enquanto que o grupo controle permaneceu soronegativo pelo teste de ELISA indireto. O desempenho idêntico das duas cepas de $C$. chauvoei após o desafio in vivo e a incapacidade de infectar os animais vacinados está correlacionado com a homologia genética das cepas. Além disso, ambas as vacinas comerciais demonstraram uma adequada eficácia protetiva contra as cepas de campo e de referência. Embora o insucesso das vacinações contra C. chauvoei tenha sido previamente relatado, os resultados deste estudo, juntamente com a alta similaridade genética reportada previamente em cepas provenientes de diferentes continentes sugerem que as falhas vacinais não estão relacionadas à variabilidade antigênica, mas sim ao manejo vacinal inadequado.

Palavras-chave: Carbúnculo sintomático. Clostridiose bovina. Mionecrose. Bacterina. Avaliação.

\section{Introduction}

Clostridium chauvoei is a Gram positive, anaerobic, spore-forming bacterium that causes blackleg, a highly fatal disease of cattle and sheep. In many countries, this disease leads to significant economic losses in livestock production. Cattle have been vaccinated against common clostridial diseases, including C. chauvoei, for more than 70 years (UZAL, 2012). The first vaccine against this disease was developed by Arloing, Cornevin, and Tomas in 1889, based on empirical knowledge of the infectious agent (LOPES, 1977). In contrast to other clostridial vaccines, which consist of toxoids, blackleg vaccines are prepared from formalin-killed whole-cell bacteria (CHANDLER; GULASEKHARAM, 1974). The efficacy of commercial clostridial vaccines against $C$. chauvoei, Clostridium botulinum, and Clostridium perfringens is regulated by the Pharmacopoeia of the countries where the vaccines are used.

In 1977, Reed and Reynolds reported failures of C. chauvoei vaccinations against blackleg. The possible reasons for these vaccination failures were thought to be differences in the infecting C. chauvoei strains. Therefore, it was suggested that this problem could be solved by adding an inactivated field strain to the vaccine (WOOLCOCK; FROST, 1978). Several studies have evaluated the protective effect of vaccines and the antigenic variation in the flagella and cellular antigens of $C$. chauvoei (CHANDLER; GULASEKHARAM, 1974; KOJIMA et al., 2000; TAMURA et al., 1995, 1992; TAMURA; TANAKA, 1984, 1987; TANAKA et al., 1987). The guinea pig model was considered to be a valid indicator of field performance for $C$. chauvoei antigen vaccines (CRICHTON et al., 1986). Although many speculative studies have investigated the soluble antigens of $C$. chauvoei, in particular the toxins, only the leucocidin, $C$. chauvoei toxin A (CctA) was shown to induce protective immunity against blackleg (FREY et al., 2012). Only two potential virulence factors, the leucocidin CctA and the neuraminidase/sialidase NanA, have been functionally and genetically investigated (FREY et al., 2012; FREY; FALQUET, 2015; VILEI et al., 2011). Recently, a broad genomic study showed that twenty strains of $C$. chauvoei isolated from four continents over a period of 60 years showed high genetic homology, indicating identical phenotypes (RYCHENER et al., 2017). Therefore, a vaccine made from any strain should provide universal protection, which is in contrast to some reports on blackleg outbreaks in vaccinated cattle, where antigenic variations were expected and the inclusion of local strains was promoted to improve vaccines (CORPUS et al., 2008; DUTRA et al., 2011; GACEM et al., 2015; MIRANDA et al., 2008; ORTIZ-ORTEGA et al., 2012).

The aim of this study was to verify the protective efficacy of two commercial vaccines against a virulent field strain (SBP 07/09) and the reference strain MT (Manguinhos-Teixeira) that is used as a control for blackleg vaccines according to Brazilian Legislation Portaria-SDA n ${ }^{\circ} .49 / 97$ (BRASIL, 1997) and to characterize the strains used in the challenge by whole genome sequencing and antimicrobial susceptibility testing. 


\section{Materials and Methods}

\section{Bacterial strains used}

Clostridium chauvoei strain MT is a reference strain that is used for vaccine efficacy determinations and was obtained from the National Agricultural and Livestock Laboratory (Lanagro), Rio Grande do Sul. Field strain SBP 07/09 (Identification by the Laboratory of Bacteriology in the Research Area) was isolated from a naturally infected cow belonging to a vaccinated herd on a farm located in the central region of the Rio Grande do Sul state $\left(29^{\circ}\right.$ $\left.32^{\prime} \mathrm{S}, 53^{\circ} 51^{\prime} \mathrm{W}\right)$, Brazil in 2009 . The identity of the isolate was confirmed by polymerase chain reaction (PCR) amplification of the $\mathrm{fliC}$ gene according to the protocol of Sasaki (2002) and rrs (16S rRNA) gene sequencing.

Characterization of the strains used in the challenge

Bacterial DNA was extracted according to the protocol of Takeuchi et al. (1997). Primer pairs targeting the $C$. chauvoei cctA and nanA gene sequences were designed using Primer-BLAST (NCBI, USA) and are shown in Table 1. DNA was amplified by PCR in a $25 \mu \mathrm{l}$ reaction comprising $1 \times$ enzyme buffer containing $1.5 \mathrm{mM}$ magnesium chloride (Promega, USA), $20 \mathrm{mM}$ each dNTP (Ludwig Biotec, Brazil), 1.25 U of Taq DNA polymerase (Promega, USA), $10 \mathrm{mmol}$ each primer, ultrapure water qsp (Invitrogen, USA), and $1 \mu \mathrm{L}$ of template DNA. The reactions were carried out in a Veriti 96-well Thermal Cycler (Applied Biosystems, USA). The reaction conditions were as follows: $94^{\circ} \mathrm{C}$ for $5 \mathrm{~min} ; 35$ cycles of $95^{\circ} \mathrm{C}$ for $50 \mathrm{~s}, 61^{\circ} \mathrm{C}$ for $50 \mathrm{~s}($ cctA $)$ or $62^{\circ} \mathrm{C}$ for $50 \mathrm{~s}($ nan $A)$, and $72^{\circ} \mathrm{C}$ for $7 \mathrm{~min}$, followed by a final extension at $72^{\circ} \mathrm{C}$ for $4 \mathrm{~min}$. The amplification products were analyzed by $1.5 \%$ agarose gel electrophoresis and ethidium bromide staining. PCR products were sequenced by ACTGene Molecular Analysis LTDA (Biotechnology Center, UFRGS, Porto Alegre, RS, Brazil).

Table 1. Primers used for PCR.

\begin{tabular}{lllll}
\hline Gene & Direction & Amplicon $(\mathbf{b p})$ & Sequence $\left(\mathbf{5}^{\prime}\right.$ to $\mathbf{3}^{\prime}$ ) & Reference \\
\hline$c c t A$ & Forward & 1120 & TGCTTGCTTTAGCAACAACAACT & JQ728486* \\
$c c t A$ & Reverse & & GGATGCGTCAACAATTTCTCA & Strain JF3703 \\
\hline nanA & Forward & \multirow{2}{*}{1100} & TCTTTGGCATACACCGTGGG & FM213082* \\
nanA & Reverse & & CATCCCAAGTTACCCCACCA & Strain JF4135 \\
\hline
\end{tabular}

*GenBank accession number.

The antimicrobial susceptibility of the strains used in the challenge was determined in 96-well broth microdilution plates containing Brucella Broth (Sensititre ${ }^{\mathrm{TM}}$ ANO2B susceptibility plates for anaerobic organisms; Trek Diagnostics Systems Ltd., England). The minimal inhibitory concentrations (MICs) of the following antibiotics were determined using the listed concentrations: ampicillin/sulbactam, $\quad 0.5 / 0.25-16 / 8 \quad \mu \mathrm{g} \quad \mathrm{ml}^{-1}$; amoxicillin/clavulanic acid, 0.5/0.25-16/8 $\mu \mathrm{g} \mathrm{ml}^{-1}$; cefotetan, 4-64 $\mathrm{g} \mathrm{m} \mathrm{m}^{-1}$; penicillin, 0.06-4 $\mu \mathrm{g} \mathrm{ml}^{-}$
1; imipenem, 0.12-8 $\mu \mathrm{g} \mathrm{ml}^{-1}$; meropenem, 0.5-8 $\mu \mathrm{g} \mathrm{ml} \mathrm{m}^{-1}$; clindamycin, $0.25-8 \mu \mathrm{g} \mathrm{ml}^{-1}$; cefoxitin, 1-32 $\mu \mathrm{g} \mathrm{ml}^{-1}$; metronidazole, 0.5-16 $\mu \mathrm{g} \mathrm{ml}^{-1}$; chloramphenicol, 2-64 $\mu \mathrm{g} \mathrm{ml}^{-1}$; ampicillin, 0.5-16 $\mu \mathrm{g} \mathrm{ml}^{-1}$; piperacillin, 4-128 $\mathrm{g} \mathrm{m} \mathrm{ml}^{-1}$; tetracycline,

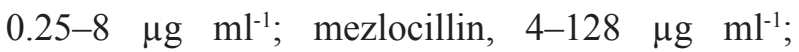
piperacillin/tazobactam, $0.25 / 4-128 / 4 \quad \mu \mathrm{g} \mathrm{ml}^{-1}$. The procedure and interpretation of the results were performed according to the manufacturer's instructions. A quality control test was conducted using Clostridium septicum ATCC 8065. 
Whole genome sequencing assembly and annotation

The full genomes of the two C. chauvoei strains, MT and SBP 07/09, were sequenced by GATCBiotech (Konstanz, Germany) using the Illumina ${ }^{\circledR}$ HiSeq 2500/3000 (150 bp paired-end reads) platform according to the manufacturer's protocols. The genome coverage varied from $50 \times$ to $1000 \times$. The genome assembly was performed using the Geneious $^{\circledR}$ de novo assembly algorithm (Biomatters Ltd., Auckland, New Zealand). The whole genomes were annotated using Prokka (SEEMANN, 2014) and MicroScope (VALLENET et al., 2013). The sequence accession numbers for strains MT and SBP 07/09 are SRR5429445 and SAMN08623026, respectively.

\section{Vaccination and challenge in immunized guinea pigs}

Guinea pigs were vaccinated with one of the two polyvalent inactivated vaccines that are commercially available in Brazil. Vaccine A contains seven different clostridial antigens in a single dose: C. chauvoei bacterin, C. perfringens A/C/D, $C$. septicum, and $C$. novyi and $C$. tetani toxins, and vaccine $B$ contains nine different antigens: C. chauvoei and C. haemolyticum bacterins, $C$. perfringens $\mathrm{B} / \mathrm{C} / \mathrm{D}, C$. septicum, $C$. novyi, and $C$. tetani and $C$. sordellii toxins.

Immunized guinea pigs were challenged according to MAPA regulation (BRASIL, 1997) as described below. Guinea pigs (Cavia porcellus) weighing approximately $400 \mathrm{~g}$ were provided by Lanagro-São Paulo. The lethal dose $\left(\mathrm{LD}_{50}\right)$ of the field strain SBP 07/09 was calculated according to the method of Reed and Muench (1938), and the concentration was determined to be $1 \times 10^{5} \mathrm{LD}_{50}$ $\mathrm{mL}^{-1}$. The sporulated MT reference strain, which is routinely used for efficacy testing of commercially available clostridial vaccines in Brazil, was provided by Lanagro-Rio Grande do Sul at a titration of $6 \times$ $10^{4} \mathrm{LD}_{50} \mathrm{~mL}^{-1}$ (FARIAS, 2011).

The guinea pigs were divided into six groups: four vaccinated groups and two control groups. For the vaccinated groups, two groups of eight guinea pigs received vaccine $\mathrm{A}(0.8 \mathrm{ml})$ and two groups received vaccine $\mathrm{B}(0.6 \mathrm{ml})$. The two control groups, composed of five guinea pigs each, were left unvaccinated. Twenty-one days after the first vaccination, the animals were revaccinated. The vaccinations were one-fifth of the bovine dose recommended by the manufacturer and were administered subcutaneously in the ventral thoracic area (BRASIL, 1997; FARIAS, 2011).

At 14 days after revaccination, both the vaccinated and control animals were intramuscularly challenged with $0.5 \mathrm{~mL}$ of a $C$. chauvoei spore suspension containing $100 \times \mathrm{LD}_{50}$ of the MT reference strain and SBP $07 / 09$ field strain in $5 \% \mathrm{CaCl}_{2}$ (Inlab, Brazil). After challenge, the guinea pigs were observed for 72 hours, and deaths that occurred during this period were recorded. According to Brazilian legislation Portaria-SDA n ${ }^{\circ} .49 / 97$, evidence is considered valid when at least $4 / 5$ sentinel animals do not survive the challenge, and the vaccine should protect at least $7 / 8$ vaccinated guinea pigs to be considered efficient (BRASIL, 1997; FARIAS, 2011).

After the 72-hour observation period, serum samples were obtained from all animals and stored at $-80^{\circ} \mathrm{C}$ until analysis by enzyme-linked immunosorbent assay (ELISA). The animal study was performed in accordance with the ethical and animal welfare requirements of the Ethics Committee on Animal Research of Universidade Federal de Santa Maria (FARIAS, 2011).

\section{Enzyme-linked immunosorbent assay (ELISA)}

The positive sample used to standardize the serological test was pooled sera from all vaccinated guinea pigs, and the negative sample was pooled sera from unvaccinated guinea pigs. Bacterial antigens from the $C$. chauvoei reference strain MT (received from Lanagro-Rio Grande do Sul) and the SBP 07/09 field strain were standardized as recommended by Crichton et al. (1990) and considering the growing phase of higher immunogenicity of $C$. chauvoei culture according to Mattar et al. (2002), antigens were obtained from $C$. chauvoei cultures at the early stationary phase of growth $( \pm 14 \mathrm{~h})$ as follows. The 
culture was centrifuged at $4000 \times g$ for 20 minutes and washed twice with phosphate buffered saline (PBS; $0.14 \mathrm{M} \mathrm{NaCl}$ in $20 \mathrm{mM}$ sodium phosphate buffer, $\mathrm{pH}$ 7.2). The pellet was suspended in sodium phosphate buffer ( $\mathrm{pH} 8.9$ ), and the cells were disrupted by sonication (Ultronique QR; Ecosonics, Brazil). The concentration of each antigen as determined with the Total Protein Kit (Labtest, Brazil) was $2.65 \mu \mathrm{g} \mathrm{mL}^{-1}$ for the MT strain and 3.8 $\mu \mathrm{g} \mathrm{ml}^{-1}$ for the SBP $07 / 09$ strain. The antigens were stored at $-20^{\circ} \mathrm{C}$ until use (FARIAS, 2011).

The 96-well microplates (Nunc, Denmark) were coated with antigen diluted 1:100 in carbonatebicarbonate buffer ( $\mathrm{pH}$ 9.6) and incubated for 12 hours at $4{ }^{\circ} \mathrm{C}$. Then, the plate was washed three times with PBS plus $0.5 \%$ Tween 20 (PBS-T), incubated with blocking buffer $(1 \%$ skim milk [w/v] in PBS plus $0.05 \%$ Tween $20[\mathrm{v} / \mathrm{v}]$ ) at $37^{\circ} \mathrm{C}$ for 1 hour, and washed once more. Next, $100 \mu \mathrm{l}$ of the test and control sera were diluted 1:50 in blocking buffer, applied to the microplate, and incubated at $37^{\circ} \mathrm{C}$ for 90 minutes. The plates were washed three times with PBS-T. Then, a 1:5000 dilution of peroxidase-conjugated anti-guinea pig $\operatorname{IgG}$ produced in rabbit $\left(\right.$ Bethyl ${ }^{\circledR}$ ) was added to the plate and incubated for 90 minutes at $37^{\circ} \mathrm{C}$. After washing three times with PBS-T, the plates were incubated with o-phenylenediamine substrate solution (Sigma, USA) at room temperature. After a 15-minute incubation, the reaction was stopped by the addition of $2 \mathrm{~N}$ sulfuric acid, and the absorbance at $450 \mathrm{~nm}$ was measured with a microplate reader (FARIAS, 2011).

\section{Statistical analysis}

The ELISA data were $\log (\mathrm{x}+1)$ transformed and subjected to analysis of variance with repeated measures, and residuals were checked for normality and homoscedasticity, which are prerequisites for analysis of variance. The means were compared with Tukey's test at 5\% probability using Genes software (CRUZ, 2006).

\section{Results}

The results obtained in the vaccine efficacy trial are presented in Table 2. None of the guinea pigs in groups $\mathrm{A}$ and $\mathrm{B}$ showed clinical signs of disease and/or death after challenge, demonstrating that both vaccines protected the guinea pigs against direct challenge with $100 \times \mathrm{LD}_{50}$ of the two challenge strains. The vaccinated guinea pigs also did not present adverse reactions to vaccination or revaccination. In contrast, all animals in the control groups presented lesions characteristic for the disease, such as necrosis and increased muscle mass at the inoculation site, and all animals died 24-48 hours after inoculation (FARIAS, 2011).

Table 2. Results of the guinea pig challenge experiment with the Clostridium chauvoei reference strain MT(ManguinhosTeixeira) and the field strain SBP 07/09 (Identified by the Laboratory of Bacteriology) in animals immunized with one of two polyvalent clostridial vaccines (A and B). The mean \pm standard deviation humoral response of the guinea pigs is expressed as the optical density (OD) of the ELISA. *Antigens used for plate sensitization.

\begin{tabular}{|c|c|c|c|c|}
\hline \multirow[t]{3}{*}{ Groups } & \multirow{3}{*}{ Challenge strains } & \multirow{3}{*}{$\begin{array}{c}\text { Challenge results (no.) } \\
\text { Protected/challenged }\end{array}$} & \multicolumn{2}{|c|}{ Serological response } \\
\hline & & & \multicolumn{2}{|c|}{ Mean $O D$} \\
\hline & & & $M T^{*}$ & SBP 07/09* \\
\hline \multirow{2}{*}{ Vaccine $A$} & $M T$ & $8 / 8$ & $0.277 \pm 0.014^{\mathrm{ab}}$ & $0.318 \pm 0.009^{\mathrm{B}}$ \\
\hline & SBP 07/09 & $8 / 8$ & $0.182 \pm 0.050^{b}$ & $0.255 \pm 0.019^{\mathrm{C}}$ \\
\hline \multirow{2}{*}{ Vaccine $B$} & $M T$ & $8 / 8$ & $0.367 \pm 0.015^{\mathrm{a}}$ & $0.405 \pm 0.006^{\mathrm{A}}$ \\
\hline & SBP 07/09 & $8 / 8$ & $0.291 \pm 0.034^{\mathrm{ab}}$ & $0.355 \pm 0.066^{\mathrm{AB}}$ \\
\hline \multirow{2}{*}{ Control } & $M T$ & $0 / 5$ & \multirow{2}{*}{\multicolumn{2}{|c|}{$\begin{array}{l}0.048 \pm 0.002^{\mathrm{cD}} \\
0.049 \pm 0.001^{\mathrm{cD}}\end{array}$}} \\
\hline & SBP 07/09 & $0 / 5$ & & \\
\hline
\end{tabular}

Means followed by different letters (lower case in the MT column, standard error: 20.38\%, and upper case in the SBP $07 / 09$ antigen column, standard error 7.99\%) are significantly different by Tukey's test $(\mathrm{P}<0.05)$. Adapted from Farias $(2011)$. 
The four vaccinated and challenged groups showed seroconversion after immunization. The mean ODs in the ELISA by group are presented in Table 2. The control group remained seronegative. Guinea pigs inoculated with vaccine B had higher ODs than guinea pigs inoculated with vaccine A. Significant differences in mean OD were observed by Tukey's test $(\mathrm{P}<0.05)$ between animals vaccinated with vaccine $B$ and challenged with the reference strain (MT) and animals vaccinated with vaccine A and challenged with the field strain (SBP 07/09), regardless of the coating antigen used in the microplates. When the plates were coated with antigen from the MT strain, the lowest mean OD was observed in the guinea pigs immunized with vaccine A and challenged with the SBP 07/09 strain. However, there were no statistical differences in the mean OD among the vaccinated guinea pigs challenged with the two different strains. When the plates were coated with SBP 07/09 strain antigen, the lowest mean OD was observed for the guinea pigs immunized with vaccine A and challenged with the SBP 07/09 strain, and the mean OD was statistically different from that of the animals immunized with vaccine B (Table 2) (FARIAS, 2011).
Whole genome sequencing of the two challenge strains, MT and SBP 07/09, revealed only 19 single nucleotide polymorphisms (SNPs; Table 3). Nine of the SNPs were located in intergenic loci and seemed to not to be associated with regulatory RNA or promoter sequences. Three SNPs were located in open reading frames (ORFs) with known functions (ABC transporter related protein, ribose phosphate pyrophosphokinase, 50S ribosomal subunit protein L1, and alkyl-hydro-peroxide reductase), but led to only minor amino acid changes, two SNPs resulted in silent mutations in hypothetical proteins without known functions, and one SNP resulted in an amino acid change in a hypothetical, currently unassigned protein. There was $100 \%$ sequence identity in the cctA and nanA virulence genes between the two strains. For the field strain, SBP 07/09, the MIC of metronidazole was $4 \mu \mathrm{g} \mathrm{ml}^{-1}$ and that of penicillin was $0.12 \mu \mathrm{g} \mathrm{ml}{ }^{-1}$. In contrast, for the reference strain MT, the MIC of metronidazole was greater than $16 \mu \mathrm{g} \mathrm{ml}^{-1}$, and that of penicillin was $0.25 \mu \mathrm{g}$ $\mathrm{ml}^{-1}$. These differences could not be explained by genomic differences. Both strains were sensitive to all the other tested antimicrobials.

Table 3. Single nucleotide polymorphisms (SNPs) between Clostridium chauvoei strains MT and SBP 07/09.

\begin{tabular}{|c|c|c|}
\hline SNP n ${ }^{0}$. & Genetic locus & Effect \\
\hline 1 & Hypothetical protein & $\mathrm{S} 298>\mathrm{R} 298$ \\
\hline 2 & $\mathrm{ABC}$ transporter-related protein & G35 > R35 \\
\hline 3 & Ribose phosphate pyrophosphokinase & Y315 > D315 \\
\hline 4 & 50S Ribosomal subunit protein L1 & Y315 > D315 \\
\hline 5 & tRNA pseudouridine synthetase & Silent \\
\hline 6 & Hypothetical protein & Silent \\
\hline 7 & Intergenic SNP & Silent ${ }^{1)}$ \\
\hline 8 & Intergenic SNP & Silent ${ }^{1)}$ \\
\hline 9 & Transposase IS240 & Silent \\
\hline 10 & Intergenic SNP & Silent ${ }^{1)}$ \\
\hline 11 & Intergenic SNP & Silent $^{1)}$ \\
\hline 12 & Intergenic SNP & Silent ${ }^{1)}$ \\
\hline 13 & Intergenic SNP & Silent ${ }^{1)}$ \\
\hline 14 & Intergenic SNP & Silent ${ }^{1)}$ \\
\hline 15 & Intergenic SNP & Silent ${ }^{1)}$ \\
\hline 16 & $\alpha$-Mannosidase & Silent \\
\hline 17 & Intergenic SNP & Silent ${ }^{1)}$ \\
\hline 18 & Hypothetical protein & Silent \\
\hline 19 & Alkylhydroxyperoxide reductase & $\mathrm{A} 80>\mathrm{T} 80$ \\
\hline
\end{tabular}

${ }^{1)}$ no potential regulatory RNA affected. 


\section{Discussion}

The scientific evidence regarding the efficacy of vaccination against $C$. chauvoei to prevent disease and lethality in cattle is scanty (UZAL, 2012). Still, vaccination is the most efficient preventive measure to control blackleg worldwide. For example, an outbreak of blackleg in a Norwegian cattle herd that killed 72 animals over a period of 12 days was efficiently stopped by vaccination of the remaining animals (GROSETH et al., 2011).

The results obtained in this study demonstrated that the tested vaccines induced a humoral response and were able to protect the immunized animals against challenge with the standard strain (MT) and a field strain (SBP 07/09). These results differ from those of Santos (2003), who observed differences in the degree of protection in guinea pigs vaccinated and subsequently challenged with strain MT or a field strain (SP). According to the study, which included 22 batches of commercial vaccine, $95 \%$ of the vaccines conferred protective immunity when the guinea pigs were challenged with strain MT. However, when the animals were challenged with the field strain SP, only $36 \%$ of the vaccines showed protection that was sufficient for approval (SANTOS, 2003). Araujo et al. (2010) also showed a difference between the serological responses of cattle by ELISA to the field strain SP compared to the reference strain MT. Using the rapid agglutination test, Lopes (2005) demonstrated that sera from cattle immunized with commercial multivalent vaccines showed an strong immune response against the reference strain (MT) and a weak response to the field strain. The antigenic complexity of C. chauvoei and the lack of information regarding which strains are used to generate commercial clostridial immunogens impose difficulties in vaccine evaluation. Although it is not known which antigens are present in the vaccines, they appear to be antigenically related to the clostridial strains used in the challenge.
The use of serum from vaccinated guinea pigs in a C. chauvoei whole antigen ELISA for the potency test is an indirect measure of serum antibodies. This technique is traditionally used to evaluate the efficacy of vaccines containing $C$. chauvoei antigen (CRICHTON et al., 1990; HAMAOKA et al., 1990). Many authors have reported that immunity against this microorganism is stimulated primarily by cellular proteins; thus, the response can be measured by detecting the antibodies that are responsible for protection (CHANDLER, 1975; MATTAR et al., 1999; MICALIZZI; GUZMAN, 1997; STEVENSON; STONGER, 1980). Therefore, the ELISA used in this study, which was standardized to measure the humoral immune response induced after vaccination and challenge with both strains, allowed a comparison of both the vaccines and the immunogenicity of the strains. Guinea pigs inoculated with vaccine B had higher antibody levels than guinea pigs inoculated with vaccine $\mathrm{A}$, suggesting the superiority of vaccine B in inducing a humoral response when compared with vaccine $\mathrm{A}$. The greatest difference was observed between the vaccine B group challenged with the MT strain and the vaccine A group challenged with the field strain. When comparing the antibody titers of the animals in groups A and B, we observed that the antibody levels were higher in the guinea pigs that were challenged with MT than in those challenged with the field strain. However, no statistical difference was detected between the animals immunized with vaccine $B$ and challenged with the field strain and animals immunized with vaccine $\mathrm{A}$ and challenged with MT. These results agree with a study showing that the humoral response to the field strain was also lower than the response to the MT strain in some cases (ARAUJO et al., 2010). Although there are differences in the responses to both strains and both vaccines, the challenge strains showed the same results in the ELISA test, and there was no difference in vaccine protection. 
Studies have examined the differences in the immunogenicity and virulence of $C$. chauvoei strains (CHANDLER; GULASEKHARAM, 1974; KIJIMA-TANAKA et al., 1998; MATTAR et al., 1999; NAZ et al., 2005). In addition, the existence of non-flagellated mutants with significantly lower virulence and immunogenicity was proposed by Kijima-Tanaka et al. (1994) and Tamura et al. (1995), and variation in the immunogenic proteins and cellular antigens according to growth phase was asserted by Mattar et al. (2002). The causes of vaccine failure were assumed to be antigenic differences between the strains used to generate the vaccines and the infecting strain (DUTRA et al., 2011). In our study, no clinical disease or death was observed in guinea pigs immunized with vaccine $A$ or B and subsequently challenged with one of the two strains, thus the vaccines showed the same degree of protection. In addition, genomic analysis of the field strain SBP 07/09 demonstrated nearly 100\% genomic identity with the MT strain, and $100 \%$ identity for the virulence genes $\operatorname{cct} A$ and nanA. This high degree of homology between the two challenge strains agrees with a recent genomic analysis of 20 C. chauvoei strains collected worldwide over the last 60 years, which revealed high sequence conservation, showing that $C$. chauvoei has reached an evolutionary dead end (RYCHENER et al., 2017).

Clostridia are generally sensitive to penicillin, tylosin, metronidazole, florfenicol, and vancomycin (SALVARANI et al., 2012; SILVA et al., 2014). In this study, the MICs differed between the reference strain (MT) and the field strain (SBP 07/09), and were superior in the reference strain.

Polyvalent vaccines are largely used in beef cattle, as they show various advantages, such as time savings, allowing immunization of large populations. However, these vaccines often contain too many pathogens, even without evidence of their occurrence in the region where the vaccine is being used. In addition, vaccine indications are not always the same for all agents (e.g., age at first vaccination, number of booster doses, time elapsed between the first immunization and booster, and route of administration) (GASPAR; SANTOS, 2014). With regard to the important antigens of $C$. chauvoei, there is concern that this pathogen produces little toxin under some in vitro growth conditions. This low level of toxin, together with the other antigens in the vaccine, leads to dilution, which could reduce its protective efficacy against blackleg (LOPES, 1977). However, a study assessing the serological response of bovines to a combination vaccine containing foot and mouth disease virus, rabies virus, Pasteurella multocida, and C. chauvoei antigens compared to the individual component vaccines showed no significant difference in the serological response elicited by individual component vaccines and the combined vaccine containing four antigens at 21 and 90 days post vaccination (SRINIVASAN et al., 2001). Hanna et al. (2014) also found no significant difference in C. chauvoei and C. septicum antibody titers between bivalent Clostridial and Pasteurella vaccines in sheep. In our study, although both vaccines protected guinea pigs against challenge, the average OD was higher in animals immunized with vaccine $\mathrm{B}$, which was composed of nine different antigens.

Despite the increasing call to reduce in vivo studies, animal models remain the most robust for evaluating certain responses. Buys et al. (2014) developed an indirect cytometric bead immunoassay for use in vaccine potency testing, and the results were compared to those obtained using an indirect ELISA and an in vivo mouse neutralization test. However, the in vitro alternatives tested by Buys et al. (2014) did not have sufficiently satisfactory results to allow their substitution for animal studies. Currently, challenge in immunized guinea pigs is the method that is legally required for the release of vaccines. The current legislation in several countries has standards for vaccines containing $C$. chauvoei that require efficacy testing of all vaccine batches 
by both the manufacturer and official agencies (BRASIL, 1997; BRITISH PHARMACOPEIA, 1998; USDA, 2003). However, we expect that knowledge of the major protective antigens, such as CctA, NanA, and NagH (hyaluronidase), will allow animal testing to be replaced by in vitro methods (RYCHENER et al., 2017).

While recent findings clearly show no antigenic variation between $C$. chauvoei strains from various locations worldwide (RYCHENER et al., 2017), differences in toxin expression levels could be responsible for the observed variations in the clinical signs of the disease. Furthermore, vaccine efficacy could be strongly affected by the differential expression of toxins as protective antigens, depending on minor differences in growth medium composition or fermentation processes. Controlling these factors will further improve the quality of blackleg vaccines. However, is should be noted that most of the informal and formal reports of blackleg cases in Brazil are related to unvaccinated herds or management failures, such as non-application of the booster vaccination.

\section{Conclusion}

The two tested clostridial vaccines induced humoral responses and were able to protect guinea pigs against challenge with a field strain (SBP 07/09) and the reference strain (MT). The similar performance of the two strains in the challenge and ELISA are correlated with the high degree of genome sequence homology.

The results of this study, together with the consolidated knowledge on this subject, reiterate the importance of vaccination as the main preventive measure against blackleg, especially in herds located in endemic areas. It is also important to mention the importance of effective vaccine management and using the correct route of administration, dose, and booster timing.

\section{Conflicts of interest:}

The authors declare no conflict of interests.

\section{Acknowledgements}

The authors are thankful forfinancial support from the Coordenação de Aperfeiçoamento de Pessoal de Nível Superior (CAPES), Conselho Nacional de Desenvolvimento Científico e Tecnológico (CNPq), and Fundação de Amparo à Pesquisa do Estado do Rio Grande do Sul (FAPERGS) and from Research Foundation 3R (Reduction, Refinement and Replacement of Animal Experimentation; grant no. 136-13 to JF). The reference strain was provided by Lanagro-RS (CGAL/SDA-MAPA, Porto Alegre, $\mathrm{RS}$ ), and guinea pigs were provided by LanagroSP (CGAL/SDA-MAPA, Campinas, SP). We thank Geder Paulo Herrmann, Carlos Eugênio Soto Vidal, and SAMITEC (Soluções Analíticas Microbiológicas e Tecnológicas, Santa Maria, RS) for assistance with the guinea pigs.

\section{References}

ARAUJO, R. F.; CURCI, V. C. L. M.; NOBREGA, F. L. C.; FERREIRA, R. M. M.; DUTRA, I. S. Vaccination protocol and bacterial strain affect the serological response of beef calves against blackleg. Pesquisa Veterinária Brasileira, v. 30, n. 7, p. 554-558, 2010. DOI: $10.1590 / \mathrm{S} 0100-736 \mathrm{X} 2010000700008$

BRASIL. Ministério da Agricultura, Pecuária e Abastecimento. Portaria n. 49 de 12 de maio de 1997. Diário Oficial [da] União, Brasília, 16 de maio de 1997. Seção 1, p. 10168-10169.

BRITISH PHARMACOPEIA. Veterinary Antisera and Veterinary Vaccines. 3. ed. Sainte Ruffine: Maisonneuve S.A., 1998.

BUYS, A.; MACDONALD, R.; CRAFFORD, J.; THERON, J. Development of a flow cytometric bead immunoassay and its assessment as a possible aid to potency evaluation of enterotoxaemia vaccines. Journal of the South African Veterinary Association, v. 85, n. 1, p. 977,2014 . DOI: 10.4102/jsava.v85i1.977. Available at: http://www.ncbi.nlm.nih.gov/pubmed/24832497. Accessed at: 03 mar. 2017. 
CHANDLER, H. M. Rabbit immunoglobulin responses to the flagella, somatic, and protective antigens of a highly protective strain of Clostridium chauvoei. Infection and Immunity, v. 12, n. 1, p. 143-147, 1975.

CHANDLER, H. M.; GULASEKHARAM, J. The protective antigen of a highly immunogenic strain of Clostridium chauvoei including an evaluation of its flagella as a protective antigen. Journal of General Microbiology, v. 84, n. 1, p. 128-134, 1974. DOI: 10.1099/00221287-84-1-128

CORPUS, M. D. L. O.; ANDRADE, L. H.; MENDEZ, J. L.; GUTIERREZ, V. T. Prevention of blackleg by an immunogen of Clostridium chauvoei. Annals of the New York Academy of Sciences, v. 1149, n. 1, p. 303-305, 2008. DOI: $10.1196 /$ annals. 1428.013

CRICHTON, R.; HARRISS, D. A; MCKAY, D. J. Standards for Clostridium chauvoei vaccine the relationship between the response of guinea-pigs and sheep following vaccination and challenge with virulent Clostridium chauvoei. Australian Veterinary Journal, v. 63, n. 3, p. 68-70, 1986. DOI: 10.1111/j.1751-0813.1986. tb02931.x

CRICHTON, R.; SOLOMON, J.; BARTON, A. M. The development of an enzyme-linked immunosorbent assay for measuring the potency of vaccines containing Clostridium chauvoei antigens. Biologicals: Journal of the International Association of Biological Standardization, v. 18 , n. 1, p. 49-54, 1990. DOI: 10.1016/1045-1056(90)90070-G

CRUZ, C. D. Programa genes: biometria. Viçosa: UFV, 2006. 382 p.

DUTRA, I. S.; SOUZA, A. M.; BORSANELLI, A. C. Escolha da vacina define a eficácia dos programas preventivos contra clostridioses. In: WORKSHOP VACINAS E VACINAÇÕES NA BOVINOCULTURA, Ribeirão Preto, 2011. Anais... Jaboticabal: Athenas Gráfica e Editora, 2011. v. 1, p. 97-130.

FARIAS, L. D. Carbúnculo sintomático: abordagem diagnóstica e imunológica. 2011. Dissertação (Mestrado em Medicina Veterinária) - Universidade Federal de Santa Maria, Santa Maria, 2011. 61 p.

FREY, J.; FALQUET, L. Patho-genetics of Clostridium chauvoei. Research in Microbiology, v. 166, n. 4, p. 384392, 2015. DOI: 10.1016/j.resmic.2014.10.013

FREY, J.; JOHANSSON, A.; BÜRKI, S.; VILEI, E. M.; REDHEAD, K. Cytotoxin CctA, a major virulence factor of Clostridium chauvoei conferring protective immunity against myonecrosis. Vaccine, v. 30, n. 37, p. 5500-5505, 2012. DOI: 10.1016/j.vaccine.2012.06.050. Available at: http://www.ncbi.nlm.nih.gov/pubmed/ 22749595. Accessed at: 10 mar. 2016.

GACEM, F.; MADADI, M. A.; KHECHA, N.; BAKOUR, R. Study of vaccinal properties of Clostridium chauvoei strains isolated during a blackleg outbreak in cattle in Algeria. Kafkas Universitesi Veteriner Fakultesi Dergisi, v. 21, n. 6, p. 825-829, 2015. DOI: 10.9775/ kvfd.2015.13616

GASPAR, E. B.; SANTOS, L. R. Vacinação de bovinos: esclarecendo algumas dúvidas. Bagé: Embrapa Pecuária Sul, 2014. 36 p.

GROSETH, P. K.; ERSDAL, C.; BJELLAND, A. M.; STOKSTAD, M. Large outbreak of blackleg in housed cattle. Veterinary Record, v. 169, n. 13, p. 339-339, 2011. DOI: $10.1136 /$ vr.d4628

HAMAOKA, T.; MORI, Y.; TERAKADO, N. Enzymelinked immunosorbent assay for evaluation of immunity in mice vaccinated with blackleg vaccine. The Japanese Journal of Veterinary Science, v. 52, n. 1, p. 167-170, 1990. DOI: $10.1292 /$ jvms 1939.52 .167

HANNA, T. N.; SELIM, A. M.; EBEID, M. H.; HOUMDA, F. K.; ELMENEISY, A. A.; GORGY, S. F. Comparative evaluation of antibody response in sheep vaccinated by bivalent clostridial and pasteurella combined vaccine. Benha Veterinary Medical Journal, v. 27, n. 2, p. 309-316, 2014.

KIJIMA-TANAKA, M.; OGIKUBO, Y.; KOJIMA, A.; SASAKI, Y. Methods Flagella based enzyme-linked immunosorbent assay for evaluation the immunity in mice vaccinated with blackleg vaccines. Journal of Microbiological Methods, v. 32, n. 1, p. 79-85, 1998. DOI: 10.1016/S0167-7012(98)00010-4

KIJIMA-TANAKA, M.; TAMURA, Y.; SUZUKI, S.; NAGAMINE, N.; NAKAMURA, M. Antigenic mimicry of Clostridium chauvoei flagella by polyclonal antiidiotypic antibodies. Journal of Medical Microbiology, v. 40 , n. 1 , p. $70-75$, 1994. DOI: 10.1099/00222615-40$1-70$

KOJIMA, A.; UCHIDA, I.; SEKIZAKI, T.; SASAKY, Y.; OGIKUBO, Y.; KIJIMA, M.; TAMURA, Y. Cloning and expression of a gene encoding the flagellin of Clostridium chauvoei. Veterinary Microbiology, v. 76, n. 4, p. 359372, 2000. DOI: 10.1016/S0378-1135(00)00256-X

LOPES, A. de A. Avaliação de imunógenos anticarbúnculo sintomático, em uso no Brasil. 1977. Dissertação (Mestrado em Medicina Veterinária) Universidade Federal de Minas Gerais, Belo Horizonte.

LOPES, B. P. Resposta sorológica em bovinos vacinados contra o Carbúnculo Sintomático. 2005. Dissertação 
(Mestrado em Medicina Veterinária) - Universidade Estadual Paulista, Jaboticabal.

MATTAR, M. A.; CORTIAS, T. I.; GUZMÁN, A. M. S. de. Immunogenic protein variations of Clostridium chauvoei cellular antigens associated with the culture growth phase. FEMS Immunology and Medical Microbiology, v. 33, n. 1, p. 9-14, 2002. DOI: 10.1016/ S0928-8244(01)00302-9

MATTAR, M. A.; CORTINAS, T. I.; DIGENARO, M. S.; STEFANINI DE GUZMAN, A. M. Immunogenic power of cellular and extracellular antigens of Clostridium chauvoei strains isolated in San Luis, Argentina. Anaerobe, v. 5, n. 3-4, p. 295-296, 1999. DOI: 10.1006/ anae. 1999.0276

MICALIZZI, B.; GUZMAN, A. M. S. Protective activity of different immunosera against Clostridium chauvoei. Anaerobe, v. 3, n. 23, p. 127-129, 1997. DOI: 10.1006/ anae. 1997.0088

MIRANDA, A.; FORT, M.; CARLONI, G.; CERVIÑO, M.; BEDOTTI, D. Evaluación de la respuesta serológica de vacunas comerciales frente a Clostridium chauvoei. Veterinaria Argentina, v. 23, n. 221, p. 130-136, 2008.

NAZ, S.; AHMAD, S.; BHATTI, J. Isolation and identification of Clostridium chauvoei from cattle and buffaloes. Pakistan Veterinary Journal, v. 25, n. 2, p. 101-102, 2005.

ORTIZ-ORTEGA, D.; VILLAMIL, L. C.; MARTINEZ, R. Isolation and typing of Clostridium spp. 16S rRNA from soil samples obtained in areas with sudden mortality history in Colombia. Global Advanced Research Journal of Microbiology, v. 1, p. 33-40, 2012.

REED, G. A.; REYNOLDS, L. Failure of Clostridium chauvoei vaccines to protect against blackleg. Australian Veterinary Journal, v. 53, n. 8, p. 393, 1977. DOI: 10.1111/ j.1751-0813.1977.tb07961.x. Available at: http://www. ncbi.nlm.nih.gov/ pubmed/588168. Accessed at: 20 mar. 2017.

REED, L. J.; MUENCH, H. A. A simple method of estimating of fifty percent endpoints. American Journal of Hygiene, v. 4, n. 27, p. 493-497, 1938. DOI: 10.1093/ oxfordjournals.aje.a118408

RYCHENER, L.; IN-ALBON, S.; DJORDJEVIC, S. P.; CHOWDHURY, P. R.; NICHOLSON, P.; ZIECH, R. E.; VARGAS, A. C. de.; FREY, J.; FALQUET, L. Clostridium chauvoei, an evolutionary dead-end pathogen. Frontiers in Microbiology, v. 8, n. 1054, p. 1-13, 2017. DOI: 10.3389/fmicb.2017.01054. Available at: https://www. ncbi.nlm.nih.gov/pmc/articles/PMC5845704/. Accessed at: 10 mar. 2017.
SALVARANI, F. M.; SILVA, R. O. S.; PIRES, P. S.; CRUZ JÚNIOR, E. C. C.; ALBEFARO, I. S.; GUEDES, R. M. C.; LOBATO, F. C. F. Antimicrobial susceptibility of Clostridium perfringens isolated from piglets with or without diarrhea in Brazil. Brazilian Journal of Microbiology, v. 43, n. 3, p. 1030-1033, 2012. DOI: $10.1590 / \mathrm{S} 1517-83822012000300027$

SANTOS, B. A. Avaliação da eficácia em cobaias de imunógenos contra carbúnculo sintomático em uso no Brasil. 2003. Tese (Doutorado em Medicina Veterinária) - Universidade Estadual Paulista, Jaboticabal.

SASAKI, Y; KOJIMA, A.; AOKI, H. Phylogenetic analysis and PCR detection of Clostridium chauvoei, Clostridium haemolyticum, Clostridium novyi types A and $\mathrm{B}$, and Clostridium septicum based on the flagellin gene. Veterinary Microbiology, v. 86, p. 257-267, 2002. DOI: $10.1016 / \mathrm{S} 0378-1135(02) 00002-0$

SEEMANN, T. Prokka: rapid prokaryotic genome annotation. Bioinformatics, v. 30, n. 14, p. 2068-2069, 2014. DOI: 10.1093/bioinformatics/btu153

SILVA, R. O. S.; D'ELIA, M. L.; TEIXEIRA, E. P. T.; PEREIRA, P. L. L.; SOARES, D. F. M.; CAVALCANTI , A. R.; KOCUVAN, A.; RUPNIK, M.; SANTOS, A. L. Q.; OLIVEIRA JUNIOR, C. A.; LOBATO, F. C. F. Clostridium difficile and Clostridium perfringens from wild carnivore species in Brazil. Anaerobe, v. 28, n. 2014, p. 207-211, 2014. DOI: 10.1016/j.anaerobe.2014.06.012

SRINIVASAN, V. A.; REDDY, G. S.; RAO, K. A.; KIHM, U. Serological response of bovines to combined vaccine containing foot and mouth disease virus, rabies virus, Pasteurella multocida and Clostridium chauvoei antigens. Veterinarski Arhiv, v. 71, n. 1, p. 37-45, 2001.

STEVENSON, J. R.; STONGER, K. A. Protective cellular antigen of Clostridium chauvoei. American Journal of Veterinary Research, v. 41, n. 4, p. 650-653, 1980.

TAKEUCHI, S.; HASHIZUME, N.; KINOSHITA, T.; KAIDOH, T.; TAMURA, Y. Detection of Clostridium septicum hemolysin gene by polymerase chain reaction. The Journal of Veterinary Medical Science, v. 59, n. 9, p. 853-855, 1997. DOI: $10.1292 /$ jvms.59.853

TAMURA, Y.; KIJIMA-TANAKA, M.; AOKI, A.; OGIKUBO, Y.; TAKAHASHI, T. Reversible expression of motility and flagella in Clostridium chauvoei and their relationship to virulence. Microbiology, v. 141, n. 3, p. 605-610, 1995. DOI: 10.1099/13500872-141-3-605

TAMURA, Y.; KIJIMA, M.; OHISHI, K.; I; TAKAHASHI, T.; SUZUKI, S.; NAKAMURA, M. Antigenic analysis of Clostridium chauvoei flagella with 
protective and non-protective monoclonal antibodies. Journal of General Microbiology, v. 138, n. 3, p. 537542, 1992. DOI: 10.1099/00221287-138-3-537

TAMURA, Y.; TANAKA, M. Opsonic activity of antiflagellar serum against Clostridium chauvoei by mouse polymorphonuclear leucocytes. Veterinary Microbiology, v. 14, n. 1 , p. $81-86,1987$. DOI: 10.1016/03781135(87)90055-1

TAMURA, Y.; TANAKA, S. Effect of antiflagellar serum in the protection of mice against Clostridium chauvoei. Infection and Immunity, v. 43, n. 2, p. 612-616, 1984.

TANAKA, M.; HIRAYAMA, N.; TAMURA, Y. Production, characterization, and protective effect of monoclonal antibodies to Clostridium chauvoei flagella. Infection and Immunity, v. 55, n. 8, p. 1779-1783, 1987.

U.S. DEPARTMENT OF AGRICULTURE - USDA, 2003. Clostridium chauvoei Bacterin. EUA. p. 634-635. Available at: https://www.govinfo.gov/content/pkg/CFR2003-title9-vol1/pdf/CFR-2003-title9-vol1-sec113-106. pdf. Accessed at: 10 mar. 2018.

UZAL, F. A. Evidence-based medicine concerning efficacy of vaccination against Clostridium chauvoei infection in cattle. The Veterinary clinics of North America. food Animal Practice, v. 28, n. 1, p. 71-7, 2012. DOI: $10.1016 / j . c v f a .2011 .12 .006$. Available at: http:// www.ncbi.nlm.nih.gov/pubmed/22374118. Accessed at: 10 mar. 2018.

VALLENET, D.; BELDA, E.; CALTEAU, A.; CRUVEILLER, S.; ENGELEN, S.; LAJUS, A.; LE FÈVRE, F.; LONGIN, C.; MORNICO, D.; ROCHE, D.; ROUY, Z.; SALVIGNOL, G.; SCARPELLI, C.; SMITH, A.A.T.; WEIMAN, M.; MÉDIGUE, C. MicroScope - an integrated microbial resource for the curation and comparative analysis of genomic and metabolic data. Nucleic Acids Research, v. 41, n. D1, p. 636-647, 2013. DOI: $10.1093 / \mathrm{nar} / \mathrm{gks} 1194$

VILEI, E. M.; JOHANSSON, A.; SCHLATTER, Y; REDHEAD, K.; FREY, J. Genetic and functional characterization of the NanA sialidase from Clostridium chauvoei. Veterinary Research, v. 42, n. 2, p. 1-9, 2011. DOI: $10.1186 / 1297-9716-42-2$

WOOLCOCK, J. B.; FROST, A. J. Failure of Clostridium chauvoei vaccines to protect against blackleg. Australian Veterinary Journal, v. 54, n. 6, p. 319-3319, 1978. DOI: 10.1111/j.1751-0813.1978.tb02476.x 